\title{
РЕЗУЛЬТАТИ ДОСЛЦДЖЕНЯ ВМІСТУ МОЛЕКУЛ СЕРЕДНЬОЇ МАСИ В ПЛАЗМІ КРОВІ ПАЦІЕНТІВ ІЗ АНЕМІЕЮ ЗЛОЯКІСНОГО НОВОУТВОРЕННЯ ПРИ РАКУ СЕЧОСТАТЕВИХ ОРГАНІВ
}

\author{
Борисенко Д. О. \\ Національний університет охорони здоров'я Украӥни імені П. Л. Шупика, \\ Київ, Україна
}

\section{Резюме}

Вступ. Рак сечового міхура (РСМ) серед онкологічних захворювань сечостатевої системи посідає друге місие в світі після раку передміхурової залози (РПЗ). На пізніх стадіях означених захворювань перебіг може супроводжувати анемія злоякісного новоутворення (АЗН).

Мета. Дослідити вміст молекул середньої маси в плазмі периферичної венозної крові пацієнтів із АЗН при уротеліальному раку сечового міхура (УРСМ) і РПЗ залежно від ступеня тяжкості анемї, оцінити можливість використання показника для діагностики і прогнозування перебігу анемії.

Матеріали іметоди. Обстежено 96 пацієнтів (64 чоловіків і 32 жінок) із УРСМ, серед них було 39 пацієнтів (28 чоловіків $i 11$ жінок), перебіг основного захворювання у яких не супроводжувався наявністю анеміі, $i 57$ пацієнтів (36 чоловіків $i 21$ жінок), перебіг основного захворювання у яких був із $A 3 H$, $i$ 48 чоловіків із РПЗ, у яких перебіг захворювання не супроводжувався АЗН (19 чоловіків), i 29 чоловіків, у яких діагностували АЗН. Вік обстежених - від 22 до 79 років. Всі пацієнти обстежені після верифікації діагнозу $і$ до початку будь-якого лікування. Вміст молекул середньої маси визначали методом за Габриэлян Н. И., Липатовой В. И. (1984). Статистичну обробку отриманих результатів проводили за допомогою методів варіаційної статистики з використанням комп'ютерної програми Microsoft Excel XP.

Результати. Досліджено вміст молекул середньої маси в плазмі периферичної венозної крові паціснтів із АЗН при УРСМ $і$ РПЗ. Установлено, щуо АЗН у пацієнтів із УРСМ $і$ РПЗ супроводжується збільшенням показника вмісту молекул середньої маси. В статті обговорюються можливі причини $i$ патогенетичні механізми виявлених змін.

Висновки. У пацієнтів із УРСМ і РПЗ відбувається розбалансування обміну молекул середньої маси, щзо проявлялося збільшенням показника їх вмісту у плазмі крові.

Ключові слова: молекули середньої маси, плазма крові, анемія злоякісного новоутворення, рак, сечовий міхур, передміхурова залоза. 
Фінансування: дослідження не мало спонсорської підтримки.

\title{
RESULTS OF THE STUDY OF THE PLASMA LEVEL OF MIDDLE MASS MOLECULES OF PATIENTS WITH MALIGNANT NEOPLASM ANEMIA WITH GENITOURINARY ORGANS CANCER
}

\author{
Borysenko D. O. \\ Shupyk National Healthcare University of Ukraine, Kyiv, Ukraine
}

\begin{abstract}
Introduction. Bladder cancer ranks second in the world among oncological diseases of the urinary system after prostate cancer. In the later stages of diseases, their course may be associated with malignant neoplasm anemia.

Aim. To study the content of middle mass molecules in plasma of peripheral venous blood of patients with malignant neoplasm anemia with urothelial bladder cancer and prostate cancer, depending on the severity of anemia. To evaluate the possible diagnostic and prognostic value of the studied indicator.

Materials and methods. 96 patients (64 men and 32 women) with urothelial bladder cancer were examined. There were 39 patients (28 men and 11 women) among them, the course of their underlying disease was not accompanied by the presence of anemia, and 57 patients (36 men and 21 women), the course of their underlying disease was aggravated by anemia of malignant neoplasm. Also, 48 men with prostate cancer whose course of the disease was not aggravated by anemia of malignant neoplasm (19 men) and 29 men were diagnosed with anemia of malignant neoplasm. The age of the patients under the survey was from 22 to 79 years. All patients were examined after verifying the diagnosis and before starting any treatment. The content of middle mass molecules in plasma was determined by the method of Gabrieljan N. I., Lipatova V. I. (1984). Statistical processing of the obtained data was conducted using the methods of variation statistics using a computer program Microsoft Excel XP.
\end{abstract}

Results. The content of middle mass molecules in plasma peripheral venous blood of patients with malignant neoplasm anemia due to urothelial bladder cancer and prostate cancer has been studied. It was found that malignant neoplasm anemia in patients with urothelial bladder cancer and prostate cancer is associated with an increase in the studied indicator. The article discusses the possible causes and pathogenetic mechanisms of the identified changes.

Conclusion. Patients with urothelial bladder cancer and prostate cancer have an imbalance of metabolism that occurs of middle mass molecules in plasma. This process is manifested by an increase in the number of middle mass molecules.

Keywords: middle mass molecules, blood plasma, malignant neoplasm anemia, cancer, bladder, prostate gland. 


\section{Вступ}

Згідно статистичних даних найпоширенішими серед онкологічних захворювань сечостатевої системи $є$ рак передміхурової залози (РПЗ) і рак сечового міхура (РСМ) $[1,2]$. Відмічають високу захворюваність на РПЗ серед чоловіків Карибського басейну, Західної Африки, Західної Америки - відповідно 79,8; 61,8 та 60,1 на 100 тис населення, в той час як найнижчу захворюваність на РПЗ відмічають в регіонах Південно-Східної і Південно-Західної Азії - 10,5 і 4,5 на 100 тис населення. У країнах Європи щорічно реєструють понад 85 тис нових випадків РПЗ, що становить близько 11-12 \% випадків всіх злоякісних новоутворень у чоловіків [3, 4]. Невтішною щодо РСМ і РПЗ є статистика і в Україні $[2,5]$.

Як правило, перебіг РПЗ і РСМ на пізніх стадіях може супроводжуватися анемічним синдром, що за патогенетичними механізмами виникає як ускладнення, або формується як самостійне захворювання - анемія злоякісного новоутворення (АЗН, шифр МКХ-10 (International Classification of Diseases (ICD) - D63.0).

Останнім часом отримано новітні дані щодо особливостей формування АЗН при пухлинах, змінилися підходи до ії лікування. Основними моментами в розвитку такої анемії вважають прогресування цитокінового інтоксикаційного навантаження на організм пацієнта, наявність оксидативного стресу, наявність спленомегалії, гемолізу, неефективного гемопоезу, гемодилюції, геморагічного синдрому, виникнення функціонального дефіциту заліза, ключовою ланкою розвитку якого $€$ зміни синтезу гепсидину [6]. Доведено, що для пухлинних клітин властивий більш інтенсивний перебіг метаболічних процесів. Групу речовин, яку назвали «молекули середньої маси» (МСM), вважають маркерами метаболічної інтоксикації, але $з$ огляду на їх фундаментальну значимість, залишаються недостатньо вивченими метаболічні процеси за їх участю у пацієнтів із пухлинами сечостатевої системи, що і спонукало нас до проведення даного дослідження.

Мета. Дослідити показник вмісту МСМ у плазмі периферичної венозної крові у пацієнтів із АЗН при РСМ і РПЗ залежно від ступеня важкості анемії, оцінити можливе діагностичне і прогностичне його значення.

\section{Матеріали і методи}

Матеріалом для дослідження була кров 96 пацієнтів (64 чоловіки і 32 жінки), хворих на уротеліальний РСМ, серед яких було 39 пацієнтів (28 чоловіків і 11 жінок), перебіг основного захворювання у яких не супроводжувався наявністю анемії (перша (I) група спостереження) і 
57 пацієнтів (36 чоловіків і 21 жінка), перебіг основного захворювання у яких був ускладнений АЗН (друга (II) група спостереження) і 48 чоловіків із РПЗ, із яких перебіг захворювання не ускладнювався АЗН (19 чоловіків) (третя (III) група спостереження) і 29 пацієнтів із РПЗ, у яких діагностували АЗН (четверта (IV) група спостереження). Вік обстежених від 22 до 79 років. Середній вік пацієнтів становив $(63,3 \pm 1,2)$ років. Усі пацієнти обстежені до початку призначення будь-якого лікування.

Ступінь важкості перебігу анемії визначали за критеріями запропонованими Національним інститутом раку (США) і виділяли: легкий ступінь анемії - гемоглобін 10-12 г/дл; середньо важкий - 8-10 г/дл; важкий - 6,5-8 г/дл; такий, що загрожує життю - нижче 6,5 г/дл [1].

Усі дослідження проводили з дотриманням основних положень Конвенції Ради Європи про права людини та біомедицину, Гельсінської декларації Всесвітньої медичної асоціації про етичні принципи проведення наукових медичних досліджень за участю людини (1964 р. 3 подальшими доповненнями, включаючи версію 2000 р.) та наказу МОЗ України № 690 від 23.09.2009 p. Усі пацієнти при госпіталізації до стаціонару були обстежені із застосуванням клінічних, лабораторних, інструментальних та спеціальних методів досліджень, у разі необхідності консультувалися фахівцями суміжних спеціальностей. У пацієнтів із уротеліальним РСМ і РПЗ проводили ретельне гістологічне вивчення препаратів, враховували характер меж пухлини із суміжними тканинами, інфільтрації, наявність пухлинних клітин в судинах, число мітозів, у тому числі атипових. Крім означеного, в пухлинах визначали клітинні елементи різного ступеня зрілості (\%) - низько диференційовані (НД), помірно диференційовані (ПД), високо диференційовані (ВД). Далі за загальноприйнятими критеріями оцінювали ступінь злоякісності та гістологічний тип пухлини.

Пацієнти із АЗН, залежно від проявів анемічного синдрому, отримували лікування відповідно до протоколів затверджених МОЗ України.

Контрольна група у дослідженні була представлена 50 первинними донорами Київського міського центру крові виконавчого органу Київської міської ради (Київської міської державної адміністрації). Вміст МСМ визначали методом за Габриэлян Н. И., Липатовой В. И. [7]. Результати дослідження вмісту МСМ у плазмі крові обстежених виражали в умовних одиницях (од) оптичної щільності, що визначали цілими значеннями в 1 мл плазми крові. Статистичну обробку отриманих результатів проводили за допомогою методів варіаційної статистики 3 використанням комп'ютерної програми Microsoft Excel XP. Достовірність різниці оцінювали, використовуючи коефіцієнт відмінності Стьюдента $(\mathrm{p}<0,05)$. 


\section{Результати та їх обговорення}

Як показав аналіз результатів дослідження, у пацієнтів із уротеліальним РСМ, серед них було 39 пацієнтів (28 чоловіків і 11 жінок), перебіг основного захворювання у яких не супроводжувався наявністю анемії (перша (I) група спостереження), вміст MCM у плазмі крові становив $(0,26 \pm 0,001)$ од, що було достовірно вище, ніж у групі контролю $(\mathrm{p}<0,05)$. Ми не виявили достовірних розбіжностей вмісту МСМ у плазмі крові пацієнтів даної групи залежно від статі (p>0,05).

Дані щодо результатів дослідження вмісту МСМ у плазмі крові залежно від ступеня тяжкості перебігу АЗН при уротеліальному РСМ (друга (II) група спостереження) та його динаміки в процесі лікування пацієнтів наводимо в таблиці 1.

\section{Таблиця 1. Динаміка вмісту МСМ у плазмі крові паціснтів із АЗН} при РСМ залежно від ступеня тяжкості перебігу в процесі лікування $(\mathrm{M} \pm \mathrm{m})$, од.

\begin{tabular}{|c|c|c|c|}
\hline \multicolumn{3}{|c|}{ Групи обстежених } & \multirow{3}{*}{$\begin{array}{l}\text { Достовірність } \\
\text { різниці (р) }\end{array}$} \\
\hline \multirow{2}{*}{$\begin{array}{c}\text { Контрольна } \\
\quad(\mathbf{n}=\mathbf{5 0})\end{array}$} & \multicolumn{2}{|c|}{$\begin{array}{c}\text { Паціснти із РСМ і АЗН } \\
(n=57)\end{array}$} & \\
\hline & до лікування & через 3 тижні & \\
\hline \multirow{8}{*}{$0,24 \pm 0,008$} & \multicolumn{2}{|c|}{ Легкий перебіг $(\mathrm{n}=21)$} & $\mathrm{p}_{1}<0,05$ \\
\hline & $0,26 \pm 0,001$ & $0,25 \pm 0,002$ & $\mathrm{p}_{2}<0,05$ \\
\hline & \multicolumn{2}{|c|}{ Середнього ступеня $(\mathrm{n}=17)$} & $\mathrm{p}_{1}<0,05$ \\
\hline & $0,29 \pm 0,002$ & $0,27 \pm 0,002$ & $\mathrm{p}_{2}<0,05$ \\
\hline & \multicolumn{2}{|c|}{ Важкий перебіг (n = 14) } & $\mathrm{p}_{1}<0,05$ \\
\hline & $0,31 \pm 0,002$ & $0,29 \pm 0,003$ & $\mathrm{p}_{2}<0,05$ \\
\hline & \multicolumn{2}{|c|}{ Такий, що загрожував життю $(\mathrm{n}=5)$} & $\mathrm{p}_{1}<0,05$ \\
\hline & $0,33 \pm 0,002$ & $0,29 \pm 0,003$ & $\mathrm{p}_{2}>0,05$ \\
\hline
\end{tabular}

Примітки: $\mathrm{p}_{1}$ - достовірність різниці порівняно 3 контролем; $\mathrm{p}_{2}$ - достовірність різниці в процесі лікування хворих

Як видно із наведених у таблиці 1 даних, по мірі прогресування анемічного синдрому вміст МСМ в плазмі крові достовірно зростав $(\mathrm{p}<0,05)$, піддавався корекції при лікуванні, але не досягав контрольних значень $(\mathrm{p}>0,05)$. Не виявили достовірних розбіжностей вмісту МСМ у плазмі крові пацієнтів даної групи залежно від статі (p >0,05).

Як показав аналіз результатів дослідження, у пацієнтів із РПЗ, серед яких було 48 пацієнтів, перебіг основного захворювання у 19 із яких не супроводжувався наявністю анемії (третя (III) група спостереження), 
вміст МСМ у плазмі крові становив $(0,26 \pm 0,002)$ од, що було достовірно вище, ніж у групі контролю $(\mathrm{p}<0,05)$. Не виявили достовірних розбіжностей вмісту МСМ у плазмі крові пацієнтів даної групи порівняно із пацієнтами I групи $(\mathrm{p}>0,05)$.

При дослідженні показника вмісту МСМ у плазмі крові пацієнтів із АЗН при РПЗ (четверта (IV) група спостереження), залежно від ступеня важкості перебігу, анемії нами встановлено наступне (табл. 2).

Таблиця 2. Динаміка вмісту МСМ у плазмі крові паціснтів із АЗН при РПЗ залежно від ступеня важкості перебігу в процесі лікування (M $\pm \mathbf{m})$, од.

\begin{tabular}{|c|c|c|c|}
\hline \multicolumn{3}{|c|}{ Групи обстежених } & \multirow{3}{*}{$\begin{array}{c}\text { Достовірність } \\
\text { різниці (p) }\end{array}$} \\
\hline \multirow{2}{*}{$\begin{array}{c}\text { Контрольна } \\
(n=50)\end{array}$} & \multicolumn{2}{|c|}{ Хворі на ЗДА $(n=73)$} & \\
\hline & до лікування & через 3 тижні & \\
\hline \multirow{8}{*}{$0,24 \pm 0,008$} & \multicolumn{2}{|c|}{ Легкий перебіг } & $\mathrm{p}_{1}<0,05$ \\
\hline & $0,26 \pm 0,002$ & $0,25 \pm 0,001$ & $\mathrm{p}_{2}<0,05$ \\
\hline & \multicolumn{2}{|c|}{ Середнього ступеня } & $\mathrm{p}_{1}<0,05$ \\
\hline & $0,30 \pm 0,002$ & $0,28 \pm 0,001$ & $\mathrm{p}_{2}<0,05$ \\
\hline & \multicolumn{2}{|c|}{ Важкий перебіг } & $\mathrm{p}_{1}<0,05$ \\
\hline & $0,32 \pm 0,002$ & $0,28 \pm 0,001$ & $\mathrm{p}_{2}<0,05$ \\
\hline & \multicolumn{2}{|c|}{ Такий, що загрожував життю } & $\mathrm{p}_{1}<0,05$ \\
\hline & $0,34 \pm 0,001$ & $0,29 \pm 0,001$ & $\mathrm{p}_{2}>0,05$ \\
\hline
\end{tabular}

Примітки: $\mathrm{p}_{1}$ - достовірність різниці порівняно із здоровими; $\mathrm{p}_{2}-$ достовірність різниці в процесі лікування хворих

Наведені в таблиці 2 дані свідчать, що у пацієнтів із РПЗ з АЗН вміст МСМ у плазмі крові зростає пропорційно збільшенню ступеня тяжкості перебігу анемії $(\mathrm{p}<0,05)$.

Як видно із результатів проведених нами досліджень, ступінь тяжкості анемії, що загрожував життю при РПЗ і РСМ, супроводжувався ендогенною інтоксикацією організму, оскільки відомо, що МСМ є універсальними маркерами ендогенної метаболічної інтоксикації. До МСМ відносять прості і складні пептиди, глікопептиди і нуклеопептиди, а також такі гуморальні регулятори як глюкагон, інсулін, різноманітні «тропіки» $\mathrm{i}$ їхні компоненти, нуклеотиди, спермін і ціла низка неідентифікованих сполук. Значну частину МСМ складають продукти розщеплення фібрину, вітаміни, гормони і гормоноїди, що потрапляють у кров із травного тракту, а також метаболіти, які утворюються при біохімічній деградації білків. Біохімічна структура МСМ є неоднаковою при різних захворю- 
ваннях і залежить від характеру патологічного процесу та його ускладнень. Основна кількість МСМ інактивується або частково руйнується в середині проксимальних тубул нирок, а вільні амінокислоти, що утворюються внаслідок означеного процесу, реабсорбуються через звичайну транспортну систему. Встановлено, що за фізіологічних умов 95 \% МСМ вилучається шляхом гломерулярної фільтрації. Зменшення екскреторної функції нирок і неповний протеоліз супроводжуються збільшенням концентрації МСМ у плазмі крові. Вміст МСМ зростає за станів, які супроводжуються метаболічною ендогенною інтоксикацією організму [7].

Цілком очевидно, що збільшення вмісту МСМ є маркером метаболічної ендогенної інтоксикації у хворих на АЗН при онкологічних захворюваннях сечостатевих органів. Показник вмісту МСМ можна розглядати як додатковий лабораторний діагностичний критерій ступеня тяжкості перебігу АЗН, оскільки їх рівень змінюється відповідно до прогресування захворювання. Ми вважаємо, що визначення показника МСМ можна рекомендувати, поряд із іншими критеріями, до широкого впровадження у практику закладів охорони здоров'я не тільки для оцінки ступеня тяжкості перебігу АЗН, їі динаміки, а й обгрунтування розширення обсягу терапевтичних заходів для корекції метаболічних порушень при цьому захворюванні. Показник вмісту МСМ у плазмі пацієнтів із АЗН є лабільним і змінюється в процесі лікування, тому, на наш погляд, його можна використовувати i для оцінки ступеня компенсації вторинних метаболічних порушень.

\section{Висновки}

Визначення показника вмісту МСМ у плазмі крові хворих на АЗН при РП3 і уротеліальному РСМ має важливе діагностичне та прогностичне значення, може бути рекомендовано як додатковий лабораторний критерій для оцінки ступеня вторинних порушень метаболізму, інтоксикаційного синдрому при означених захворюваннях, так і ефективності комплексного лікування, що проводилося.

\section{Література}

1. American Cancer Society (2010) American Cancer Society: Cancer Facts and Figures 2010. Atlanta, GA:66-71.

2. Дідик І. В. Рак передміхурової залози як світова проблема. Поширеність, фактори ризику, своєчас-

\section{References}

1. American Cancer Society (2010) American Cancer Society: Cancer Facts and Figures 2010. Atlanta, GA:66-71.

2. Didyk IV. Rak peredmichurovoi zalozy jak svitova problema. Poshyrenist' factory rysyku, svoechasnist' 
ність діагностики (огляд літератури). Український медичний часопис. 2016; 3(113):.62-64.

3. Brawley OW. Prostate cancer epidemiology in the United States. World J. Urol. 2012a; 30(2): 196200.

4. Brawley OW. Trends in prostate cancer in the United States. J. Natl. Cancer Inst. Monogr. 2012b; 45: 152-156.

5. Saidakova NO, Yatsyna OI, Stus VP, Polion MY, Kononova GE, Shilo VM. Dynamics of mortality of different laers in the population of Ukraine due to urinary bladder cancer in the regional aspect. Urologiya, 2021 ; 25(1): 5-10.

DOI: $10.26641 / 2307-$

5279.25.1.2021.231336.

6. Видиборець С. В., Андріяка А. О. Фізіологічна роль гепсидину як центрального регулятора метаболізму заліза (огляд літератури). Сімейна медицина. 2017; 1(69): 154-157.

7. Габриэлян Н. И., Липатова В. И. Опыт использования показателей средних молекул в крови для диагностики нефрологических заболеваний у детей. Лаб. дело. 1984; 3:138-140.

Стаття надійшла 16.08.2021

Контакти: vydyborets57@gmail.com diagnostuky (ogliad literatury). [Prostate cancer as a global problem. Prevalence, risk factors, diagnosis, the timelines of diagnosis (review)]. Ukrainskij medychnyi tsasopys. Ukrainian medical journal. 2016; 3(113):.62-64. [in Ukrainian].

3. Brawley OW. Prostate cancer epidemiology in the United States. World J. Urol. 2012a; 30(2): 196200.

4. Brawley OW. Trends in prostate cancer in the United States. J. Natl. Cancer Inst. Monogr. 2012b; 45: 152-156.

5. Saidakova NO, Yatsyna OI, Stus VP, Polion MY, Kononova GE, Shilo VM. Dynamics of mortality of different laers in the population of Ukraine due to urinary bladder cancer in the regional aspect. Urologiya, 2021 ; 25(1): 5-10.

DOI: $10.26641 / 2307-$ 5279.25.1.2021.231336.

6. Vydyborets SV, Andriiaka AO. Fiziologichna rol gepsidinu jak zentralnogo regulyatora meabolizmu zaliza (oglyad literatury) [The physiological role of hepcidin as a central regulator of iron metabolism (literature review). Simejna medyzyna. Family medicine. 2017; 1(69): 154157. [in Ukrainian].

7. Gabrieljan NI, Lipatova LI. Opyt issledovanija pokazatelej srednih molekul v krovi dlja diagnostiki nefrologicheskich zabolevanij $\mathrm{u}$ detej. Laboratornoe delo, 1984; 3: 138140. [in Russian] 